Short communication

\title{
IDENTIFICATION AND PARTIAL CHARACTERIZATION OF A SEX SPECIFIC PROTEIN IN KOI CARP (Cyprinus carpio haematopterus)
}

\author{
POPOVSKI Zoran ${ }^{1 *}$, KWASEK Karolina², WOJNO Michal', \\ DABROWSKI Konrad ${ }^{2}$, WICK Macdonald ${ }^{3}$
}

\begin{abstract}
${ }^{1}$ Faculty of Agriculture and Food Sciences, Ss Cyril and Methodius University, Skopje, R. of Macedonia; ${ }^{2}$ School of Environmental and Natural Resources, The Ohio State University, Columbus, OH; ${ }^{3}$ Department of Animal Sciences, The Ohio State University, Columbus, OH
\end{abstract}

(Received 11 August 2016, Accepted 22 February 2017)

Gender identification of fish species is carried out mainly by examining external morphological characteristics, which in general, it is very complex and not always a reliable approach. Electrophoresis of plasma proteins can be used as an alternative and useful molecular tool for a more precise sex determination. The presence of female specific proteins in the plasma is a starting point for the application of this technique. In this study, reducing discontinuous sodium dodecyl sulfate-polyacrylamide gel electrophoresis (SDS-PAGE) was applied to analyze plasma proteins of male and female koi carp (Cyprinus carpio haematopterus). Image analyses of electrophoregrams with resolved plasma proteins by SDS-PAGE showed that it is an appropriate technique to discriminate male from female samples. It is based on the presence of apolipoprotein B-100 which can be used as a suitable marker. Further amino acid characterization of apolipoprotein B-100 confirmed that it is a specific protein for female individuals.

Key words: koi carp, SDS-PAGE, apolipoprotein, structure

\section{INTRODUCTION}

In the past, the identification of fish gender was carried out mainly by examining the external morphological characteristics. This can have a negative impact on the fish being analyzed. A non-destructive method for gender identification of fish could prevent negative effects. Numerous studies have demonstrated the impact of proteomics on answering key biological questions; especially those that help us understand the vital functions of a living system [1]. Plasma proteins are a suitable proxy of the physiological status. Currently, electrophoresis of sarcoplasmic proteins, plasma proteins, liver proteins and a number of enzymes often have been used by some researchers as an aid in species or gender identification of fish [2]. Limited

\footnotetext{
*Corresponding author: e-mail: zoran.popovski@karpos.gov.mk
} 
studies exist on aspects of physiological changes associated with the reproductive cycle and gametogenesis. Using electrophoresis a different profile of plasma proteins appeared at different stages of maturation and attempts to trace the presence of vitellogenin were made [3]. The presence of apolipoproteins as part of plasma high density lipoproteins in female trout was reported without its characterization [4].

Proteomic technology for different applications is robust, quantitatively accurate, and high throughput analytical platform. In the recent years, mass spectrometry-based proteomics has developed into a powerful technology that is able to routinely study complex proteome samples [5]. Therefore, the objective of this study was to identify and characterize a female specific plasma protein in koi carp by a combination of electrophoretic and proteomic analyses.

\section{MATERIALS AND METHODS}

The animal handling procedures were approved on January 7, 2009 by the Institutional Animal Care and Use Committee of Ohio State University, protocol 2008A0221 that followed the federal norms and regulations.

Fourteen koi carp (Cyprinus carpio haematopterus), with a mass between 190 and 1,200 g, were obtained from the aquaculture laboratory in the School of Environmental and Natural Resources at Ohio State University, Columbus, OH (Tab. 1).

Table 1. Koi carp, sample IDs, sex and weight (grams)

\begin{tabular}{clc}
\hline Sample ID & Sex & wgt (grams) \\
\hline 1 & Male & 827 \\
2 & Female & 586 \\
3 & Female & 687 \\
4 & Female & 734 \\
5 & Male & 502 \\
6 & Male & 294 \\
7 & Male & 635 \\
8 & Female & 663 \\
9 & Male & 1,200 \\
10 & Female & 747 \\
11 & Female & 750 \\
12 & Male & 194 \\
13 & Male & 325 \\
14 & Female & 287 \\
\hline
\end{tabular}


Initial gender determination was done using a not fully reliable morphological characterization based on the common features for gender dimorphism such as pectoral fin and body shape and appearance of special white tubercles on the male head during the breeding season [6]. The blood was taken from the dorsal aorta of live individuals. Blood samples were centrifuged at 1,500 x g for 10 minutes to separate the plasma. The obtained plasma was used for protein electrophoresis.

Five hundred $\mathrm{ml}$ of plasma were thoroughly mixed in $1 \mathrm{ml}$ of sample buffer $(8 \mathrm{M}$ urea / $2 \mathrm{M}$ thiourea, $2 \mathrm{mM}$ DTT, $50 \mathrm{mM}$ Tris, 3\% SDS, 0.004\% bromophenol blue, $\mathrm{pH}$ 6.8) and incubated on ice for $30 \mathrm{~min}$. Samples were centrifuged at 10,000 $\times \mathrm{g}$ for 10 min at room temperature before loading into a $1 \mathrm{~mm} \times 12 \mathrm{~cm} \times 14 \mathrm{~cm}$ discontinuous polyacrylamide slab gel consisting of a $12.5 \%$ resolving gel [30:0.8, acrylamide/N,N0bis(methylene acrylamide)] and a 3\% stacking gel. Electrophoretic separation was carried out at a constant voltage of $10 \mathrm{Vcm}-1$. Following electrophoretic separation, the gels were imaged and analyzed as previously described [7] on a flatbed scanner. Digital images were analyzed using the Total Lab TL120 (Nonlinear Dynamics Inc., Newcastle upon Tyne, U.K.) software.

The selected band was digested with sequencing grade trypsin from Promega (Madison WI) or sequencing grade chymotrypsin from Roche T (Indianapolis, IN) using the Multiscreen Solvinert Filter Plates from Millipore (Bedford, MA).

Capillary-liquid chromatography tandem mass spectrometry (Cap-LC/MS/MS) was performed on a Thermo Scientific LTQ mass spectrometer equipped with a CaptiveSpray source (Bruker Daltonics Billerica, MA) operated in positive ion mode. The LC system was an UltiMate ${ }^{\text {TM }} 3000$ system from Thermo Scientific. The scan sequence of the mass spectrometer was based on the TopTen ${ }^{\mathrm{TM}}$ method. The analysis was programmed for a full scan recorded between 350 - $2000 \mathrm{Da}$, and a MS/MS scan to generate product ion spectra to determine amino acid sequence in consecutive instrument scans of the ten most abundant peaks in the spectrum. Sequence information from the MS/MS data was processed by converting the .raw files into a merged file (.mgf) using an in-house program, RAW2MZXML_n_MGF_ batch (merge.pl, a Perl script). The resulting mgf files were searched using Mascot Daemon by Matrix Science version 2.3.2 (Boston, MA) and the database searched against the most recent SwissProt or NCBI databases. The mass accuracy of the precursor ions were set to $1.8 \mathrm{Da}$ and the fragment mass accuracy was set to $0.8 \mathrm{Da}$. A decoy database was searched to determine the false discovery rate (FDR) and peptides were filtered according to the FDR and proteins identified required bold red peptides. Protein identifications were checked manually and proteins with a Mascot score of 50 or higher with a minimum of two unique peptides from one protein having a -b or $-\mathrm{y}$ ion sequence tag of five residues or better were accepted. 


\section{RESULTS AND DISCUSSION}

The appearance of a female specific protein in the electrophoregram of plasma proteins profile of female koi carp Cyprinus carpio haematopterus obtained by $12.5 \%$ SDS-PAGE is presented in Figure 1.

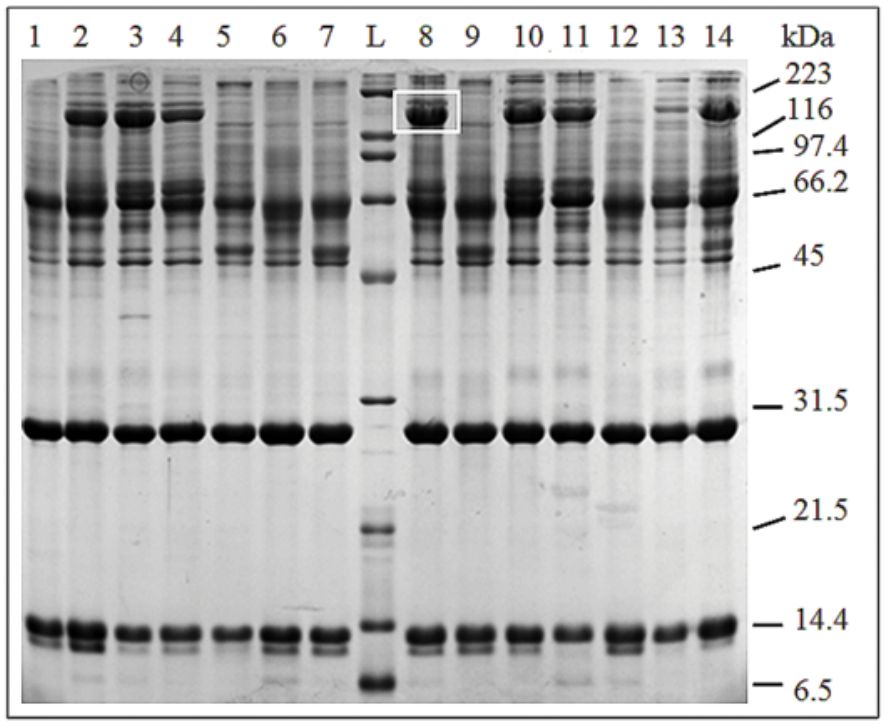

Figure 1. 12.5\% SDS-PAGE on plasma proteins from of koi carp. Lane designations presented in Table 1. Molecular weight standards in lane (L) where the sizes of bands (in $\mathrm{kDa}$ ) are given close to far right column The bend in the white box was identified as female-specific for Cyprinus carpio baematopteru)

The band in the white box was identified as being specific to the female fish and was prepared for primary protein sequence analysis (Suppl. 1).

The protein was identified as Apoliprotein B from Larimichthys a genus of ray-finned saltwater fishes commonly known as yellow croakers. Although Apolipoprotein B, in many species, has been reported to normally migrate at approximately $407 \mathrm{kDa}$, the protein identified as Apolipoprotein B, in this study, migrated at $150-200 \mathrm{kDa}$. In addition, the fragment coverage identified by MASCOT analysis spans a migration corresponding to a molecular weight of a minimum of $212 \mathrm{kDa}$ (Table 2). There is no report of the primary sequence of any Apolipoproteins in koi carp. Therefore, this discrepancy in the migration and molecular weight is possibly due to either an inherent difference in the primary protein sequence in Apolipoprotein in koi carp and/or the peptides generated and used to determine the primary sequence in the submitted band were homologous to sequences within an "Apolipoprotein-like" protein. Regardless, the plasma protein identified as Apolipoprotein in this study, is unique to the female koi carp studied. The protein is absent in the plasma of males. 


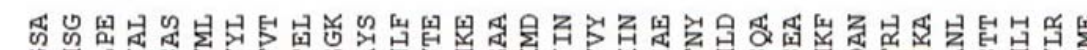

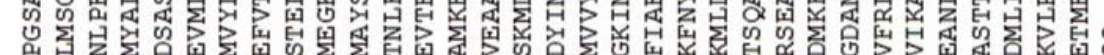

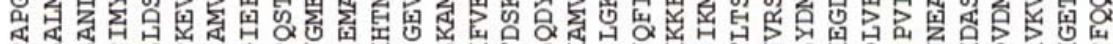

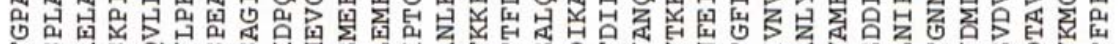

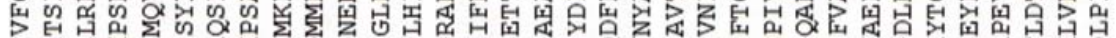

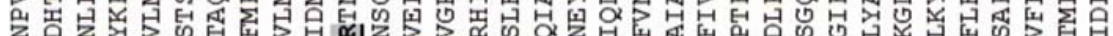

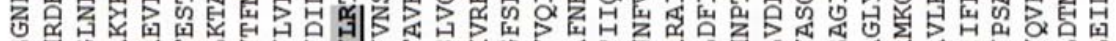

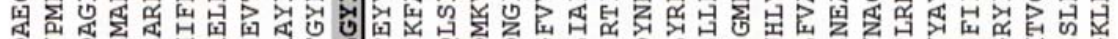

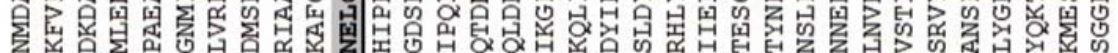

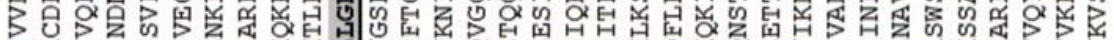

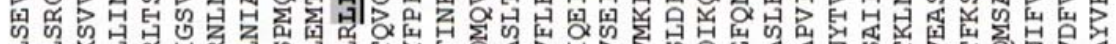

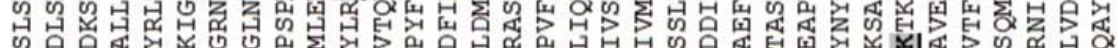

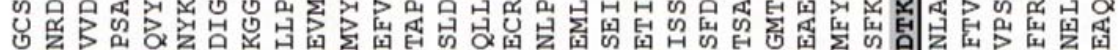

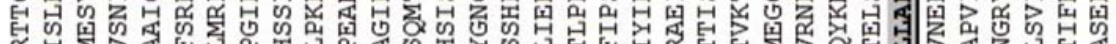

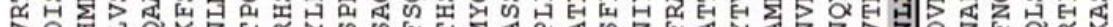

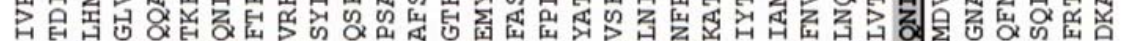

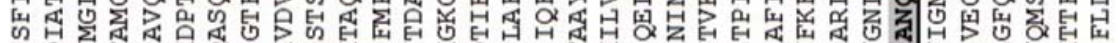

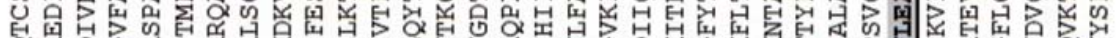

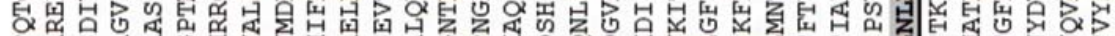

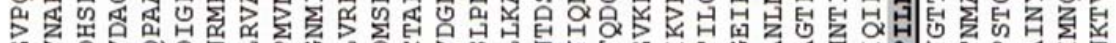

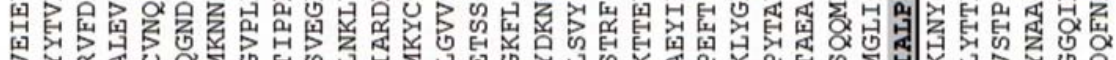

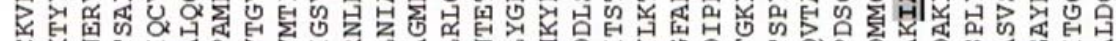

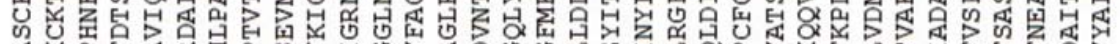

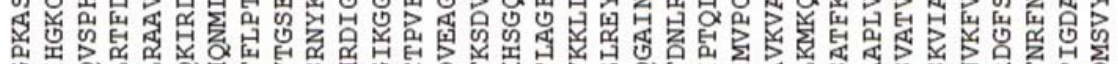

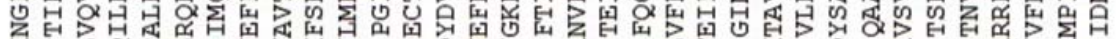

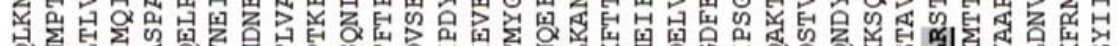

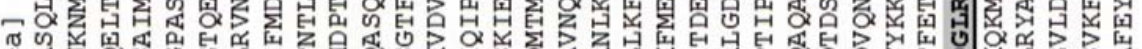

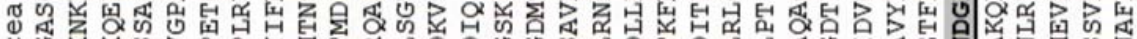

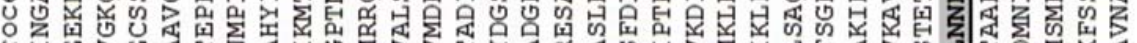

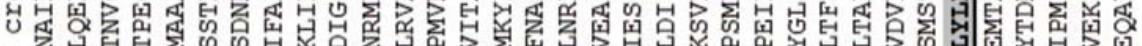

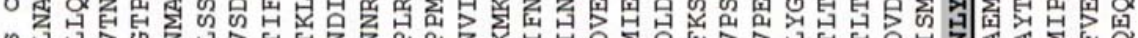

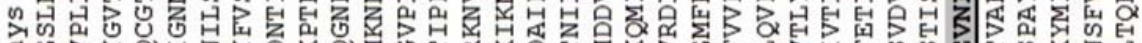

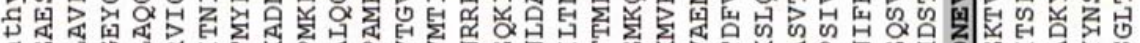

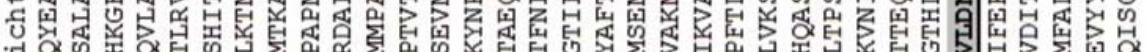

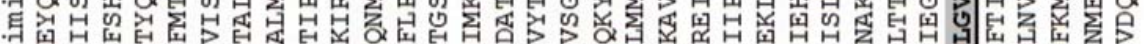

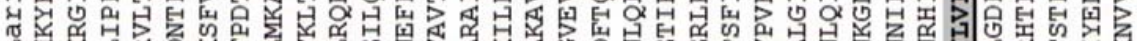

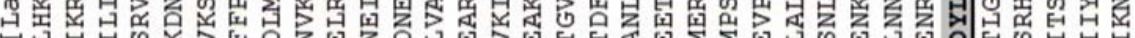

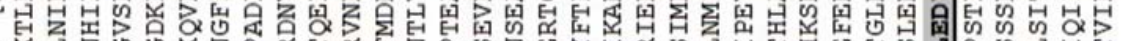

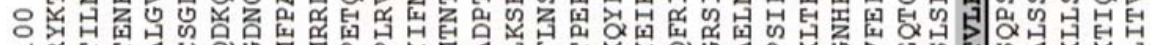

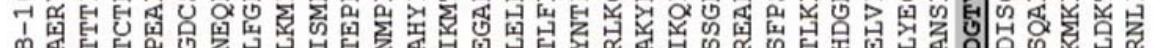

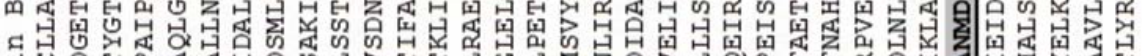

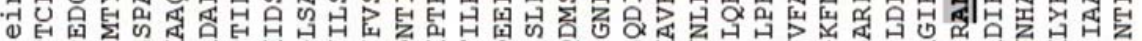

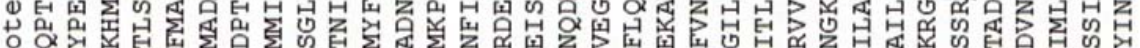

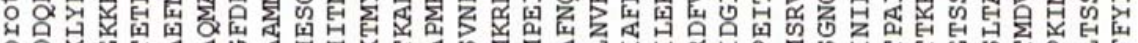

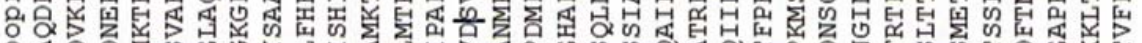

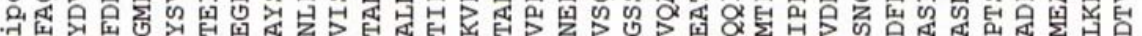

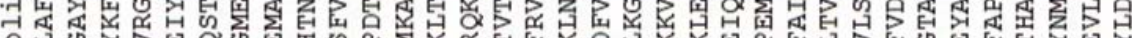

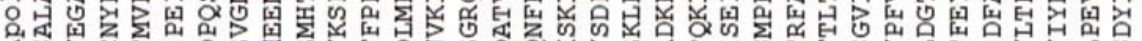

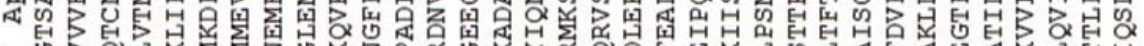

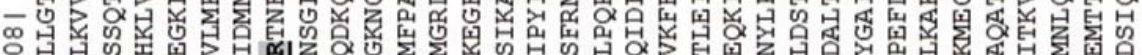

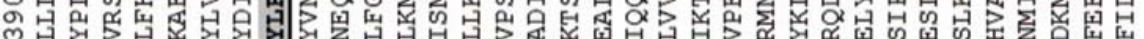

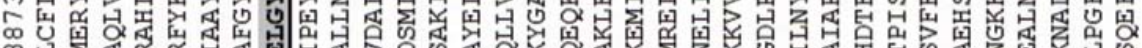

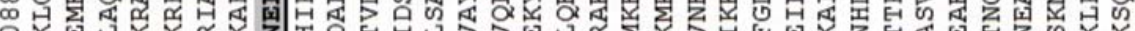

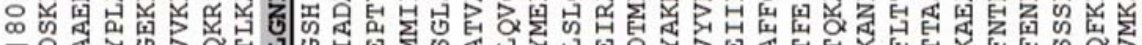

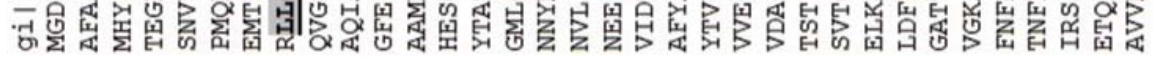


These kind of studies brought about a new look to taxonomical evaluation. Discrimination of related taxa can be easily made according to their electrophoretic results of plasma proteins [8]. SDS-PAGE can be used as a technique for gender determination of koi carp based on the identification of the presence of a female specific protein in plasma not necessarily followed by proteomics confirmation.

\section{Authors' contributions}

PZ designed the experiment, performed an electrophoretic analysis and drafted the paper. KK was involved in fish growing and lab work. WM made preliminary morphological gender identification and provided necessary fish data. DK provided the blood samples and approved the article. WM was involved in all phases of electrophoretic and proteomic analysis and did a proofreading of the text.

\section{Declaration of conflicting interests}

The author(s) declared no potential conflicts of interest with respect to the research, authorship, and/or publication of this article.

\section{REFERENCES}

1. Surinova S, Schiess R, Huttenhain R, Cerciello F, Wollscheid B, Aebersold R: On the Development of Plasma Protein Biomarkers. J Proteome Res 2011, 10:5-16.

2. Yilmaz M, Yilmaz R, Alas A: An electrophoretic taxonomic study on serum proteins of Acanthobrama marmid, Leuciscus cephalus, and Chondrostoma regium. EurAsia J BioSci 2007, 3:2227.

3. Kumar LK, Gopalakrishnan A, Mohindra V, James PB: Identification of female specific protein in seabass, Lates calcarifer (Bloch). Ind J Fish 1999, 46:375-381.

4. Babin PJ: Apolipoproteins and the association of egg yolk proteins with plasma high density lipoproteins after ovulation and follicular atresia in the rainbow trout (Salmo gairdneri). J Biol Chem 1987, 262:4290-4296.

5. Zhang H, Alvin Y L, Loriaux P, Wollscheid B, Zhou Y, Watts J, Aebersold R: Mass spectrometric detection of tissue proteins in plasma. Mol. Cell. Proteomics 2007, 6-1:64-71

6. Holmes K, Pitham T, Fletcher N: The world of Koi. Barron's Educational Series, Inc., Hauppauge, NY, 2005

7. Zapata I, Zerby H, Wick M:. Functional proteomic analysis predicts beef tenderness and the tenderness differential. J Agri Food Chem 2009, 57:4956-4963

8. Theophilus J, Rao PR: Electrophoretic studies on the plasma proteins of the three species of genus channa. Ind. J. Fish 1998, 35:294-297. 


\title{
IDENTIFIKACIJA I PARCIJALNA KARAKTERIZACIJA POLNO SPECIFIČNOG PROTEINA AZIJSKOG ŠARANA (Cyprinus carpio haematopterus)
}

\author{
POPOVSKI Zoran, KWASEK Karolina, WOJNO Michal, DABROWSKI Konrad, \\ WICK Macdonald
}

Identifikacija pola riba se izvodi prvenstveno na osnovu ispitivanja spoljašnjih morfoloških karakteristika, što predstavlja složen i ne uvek dostupan način. U tom smislu elektroforeza plazma proteina može da se koristi kao precizna i pouzdana alternativna molekularna metoda. Prisustvo proteina plazme koji su specifični za ženski pol predstavlja polaznu osnovu za primenu ove tehnike. U ovoj studiji primenjen je redukujući diskontinuirani natrijum dodecil sulfat-poliakrilamidni gel (SDS-PAGE) u cilju ispitivanja plazma proteina mužijaka i ženke Azijskog šarana (Cyprinus carpio haematopterus). Analiza slike elektroforezograma sa pomoću SDS-PAGE elektroforezom razdvojenim plazma proteinima je pokazala da je metoda odgovarajuća za diskriminaciju uzoraka prema polu. Zasnovana je na prisustvu apolipoproteina B-100 koji u ovom slučaju predstavlja pouzdan marker. Dodatna karakterizacija aminokiselina apolipoproteina B-100 je potvrdila da on predstavlja protein koji je specifičan za ženke. 